\title{
Characterization of Awassi lamb fattening systems: a Syrian case study
}

\author{
Birgitte Wiedemann Hartwell • Luis Iñiguez • \\ Joaquin Mueller • Maria Wurzinger • W. F. Knaus
}

Accepted: 18 May 2010 / Published online: 12 June 2010

(C) Springer Science+Business Media B.V. 2010

\begin{abstract}
Intensive lamb fattening systems are evolving in developing Middle Eastern countries due to high demand for lambs at favorable prices; however, little is known about their characteristics and constraints. A survey was conducted in Syria involving 241 farmers to characterize the fattening production systems and main constraints, with emphasis on feeding, management, labor, and marketing. Most farmers $(90 \%)$ considered the income from fattening to be from medium to high, and $57 \%$ expressed that lamb fattening along with alternative income sources compose the family's livelihood strategies. Fattening systems offer employment to family members. Market price was the main decision factor to buy and sell lambs, but this was only part of various marketing aspects. Male lambs usually bought at markets at the mean age of 4 months (mean weight of $31 \mathrm{~kg}$ ) are sold after fattening at a 50-60 kg weight range. The average yearly fattening cycle was 2.7 batches, and the
\end{abstract}

B. W. Hartwell • L. Iñiguez

International Center for Agricultural Research in the Dry Areas (ICARDA),

P.O. Box 5466, Aleppo, Syria

\section{J. Mueller}

Department of Animal Production, Bariloche Experimental Station, National Institute of Agricultural Technology,

Patagonia, Argentina

\section{B. W. Hartwell • M. Wurzinger • W. F. Knaus}

Division of Livestock Sciences, Department of Sustainable Agricultural Systems, BOKU-University of Natural Resources and Applied Life Sciences,

1180 Vienna, Austria

B. W. Hartwell $(\bowtie)$

Humlebaekvej 18

3480 Fredensborg, Denmark

e-mail: birhart@hotmail.com average number of lambs per batch was 232. For $65 \%$ $(n=241)$ of the farmers the major constraint to fattening was feeding cost, and for about a half of farmers $(51 \%$, $n=241$ ), disease outbreaks and prices for veterinarian services constituted the second important constraint. Research on least-cost fattening diets and curbing disease problems to increase farmer's income margins is needed. It is expected that due to existing commonalities, the information emerging from this study regarding major constraints to Awassi lamb fattening systems could be useful for an across-synthesis on Awassi fattening production in the region.

Keywords Awassi $\cdot$ Lamb fattening $\cdot$ Syria

\section{Introduction}

Local demand for meat of small ruminants is on the rise in Middle Eastern countries, in particular in Syria, Jordan, and Lebanon (Rahman 2008). Such an increase in domestic demand provides the above-listed countries with a comparative advantage for marketing lambs in the Gulf where prices for lamb meat are favorable (Rahman 2008). In Syria as in many other countries with a dry land environment, livestock rearing is often one of the only possible enterprise for farmers to engage in due to the less favorable conditions, however fundamental to maintaining traditional social activities in the areas (Rahman 2008). The demand for meat opens up income enhancing opportunities for resource-poor farmers in view of positive price differentials for their products and confirms predictions on consumption increase of livestock products fuelled by rapid population expansion, urbanization, and improved income growth (Delgado et al. 1999; Hartwell et al. 2010). 
Reflecting the described market scenario, intensive lamb fattening systems have mushroomed since the 1990s in rural and peri-urban areas of the listed Middle East countries (Bahhady et al. 1997; Rahman 2008; Vercueil and Cummins 2003). However, little, if any, information exists on these emerging systems, their characteristics, constraints, opportunities, and risks (Hartwell et al. 2010). A general encyclopedia of animal resources in the Arabian peninsula and neighboring countries were compiled in the 1980s in Arabic by the Arab Centre for studies of Arid Zones and Dry Lands in Damascus (Tleimat et al., 1981 in Arabic), but since the publication of this report, data on sub-national distribution of livestock are sparse or absent (Rahman 2008).

This work was designed to fill information gaps on lamb fattening systems, through a case study of fattening systems in Syria, targeting, in particular, the identification of key production constraints that could be mitigated by technological interventions.

It is expected that, due to existing commonalities, the information emerging from this study regarding the characteristics and major constraints to Awassi lamb fattening systems could be useful for other tropical and subtropical dry areas where a large demand for small ruminant meat provides income generation opportunities thorough fattening systems for resource-poor farmers, i.e., in Mexico (Pinos-Rodríguez et al., 2007; Zamudio et al. 2009) and Brazil (Parente et al. 2009).

\section{Materials and methods}

Survey and sampling procedures

Following a rapid appraisal survey, a constraint analysis of lamb fattening systems in Syria, focusing on farmers' coping strategies, feeding practices, management, labor input, and market access, was conducted in 2002. The survey results were validated from 2002 to 2008 while conducting on-farm fattening trials in Northeastern Syria and participatory discussion with farmers at the Aleppo sheep market (Hartwell et al. 2010).

The sampled farms were not chosen at random in each province but assembled by tracking information gathered by key persons, extension officers, people at sheep markets, and individual farmers, in each province. There were seven Syrian provinces involved in the survey totaling 241 fattening farms.

\section{Statistical analyses}

Statistical analysis used SAS procedures (SAS Institute Inc 1992). Generalized linear models were applied to quantita- tive variables (family size, years fattening, number of animals, batches, land). A principal component analysis was used to select informative variables to then conduct an average cluster analysis leading to identify groups of farms with similar features.

\section{Results and discussion}

Distribution of fattening systems and farmers' involvement in fattening

In agreement with Baltenweck et al. (2004), fattening systems occur near main roads with easy access to potential markets for buying and selling lambs, feed markets, and water sources. Few fattening systems were found in the steppe (rainfall $<200 \mathrm{~mm}$ ) although these areas encompass nearly $65 \%$ of the Syrian sheep population (Bahhady et al. 1997).

Most interviewed farmers practiced lamb fattening either with all animals purchased $(63 \%, n=241)$ or a combination of purchasing and using their own lambs to add value $(37 \%, n=241)$.

On average, the interviewed farmers experienced 23.4 years in fattening, with an expansion trend of fattening systems from the more traditional fattening areas (Aleppo, Hama and Homs) to the non-traditional areas (Hasakah, Raqqah, Dayr az-Zor, and Damascus). Shifts to more intensified sheep production were forecasted by Vercueil and Cummins (2003) and described by Rahman (2008).

Farmers learnt the production and trade from family sources $(58 \%)$ and from other sources such as market places and common rooms in villages $(42 \%)$. Most farmers (74\%) share their knowledge and get information in social networks; only a few $(4 \%, n=181)$ mentioned that the extension service was a source of information.

Importance of lamb fattening

All farmers considered lamb fattening as a good income source, more profitable, and less risky than raising sheep year-round. In most cases, the monetary contribution of lamb fattening to household income was ranked from medium $(52 \%, n=241)$ to high $(38 \%, n=241)$ and in a fewer cases, low $(10 \%, n=241)$. These ratings reflect the benefits derived from a growing demand exerted by local markets and the Gulf markets (Jaubert 2000; Rahman 2008). Thus, in line with Upton and Otte (2004), if the means to run a fattening system were available, small farmers with fewer income-generating sources would have available a diversification option.

More than half of the interviewed (57\%) had diversified livelihood involving an alternative income source besides 
fattening. Most farmers with alternative income were engaged in mixed farming systems with own cropping $(64 \%, n=137)$. Most fattening farmers $(91 \%)$ owned land. Landholding size averaged 16 ha (range, 0-200 ha) with province differences: farmers in Damascus and Dayr az-Zor owned much less land than those in Raqqah and Homs $(P<0.05)$, probably as a result of historical land distribution (Jaubert 2000) and population density.

Main features of the fattening systems

\section{Operation features}

The mean number of fattening cycles per year was 2.7 batches (range, 1-5.5 batches/year) and was relatively consistent across provinces, with farmers in Dayr az-Zor practicing the highest rate of fattening and those in Hama the lowest rate (three batches and 2.5 batches, respectively). The number of lambs fattened per batch was 232 (ranging from 15-850; Table 1).

The preferred age for buying lambs for fattening averaged 4.3 months at an average weight of $31 \mathrm{~kg}$ (Table 1). However, 96.3\% farmers use additional criteria apart from age and weight when buying lambs to be fattened: size and shape, body condition, horns, health, fat tail, and head color.

A large portion of farmers, $73 \%$ and $77 \%(n=231)$, plan lamb fattening according to season and prices, respectively. The availability of lambs for fattening is crucial. In Jordan, Lebanon, and Syria lambing occurs from December to March (Thomson et al. 2003) with plenty of lambs available from March to June and less in the fall and winter, a variation that influences lamb prices. The next important reason for planning ( $61 \%$ of $n=231$ cases) was the timing of annual celebrations (i.e., Eid) where prices of lamb meat reach higher values. Aspects such as feed availability $(41 \%, n=231)$, markets (mainly prices; $36 \%$, $n=231)$, and availability of housing $(36 \%, n=231)$ were also important to decide to fatten or not.

\section{Labor and facilities}

Usually the whole family is involved in fattening management and feeding; household size was related to the frequency and size of the fattening operation, as the linear regression of lambs fattened on household size, and number of batches per year on household size were significant.

Family members have multiple labor functions. In most cases $(98 \%)$, men have a direct function in the fattening of lambs and were the main decision-makers. This includes buying feeds, buying and selling animals, general supervision, and feed mixing. Women's involvement in fattening was not as decision-makers but in management chores (cleaning, feeding, and watering). Households with more women active in fattening tend to have more sheep $(P<0.05)$.

More than half of farmers (64\%) had transportation means: small trucks, pick-ups, tractors, or a tri-motorcycle which helps reducing the transportation costs involved.

Animal housing ranging from large concrete barns in urban areas to tents or mud stables in more peri-urban and rural areas, were available in $80 \%$ of the systems. Only $9 \%$ used tents. Farmers develop housing facilities, some functionally efficient, using their own ingenuity. Thus, while devising means to improve these systems, the local knowledge should not be ignored. The health of animals kept in large, badly ventilated enclosures such as those in urban and peri-urban areas is affected more than that of animals kept in open environments. Associated problems with feed storage included rodents $(71 \%)$, insects $(32 \%)$, and humidity $(20 \%, n=239)$ present a clear entry point for research and extension.

Table 1 Some characteristics of lamb fattening systems in Syria per province surveyed

\begin{tabular}{lcccccc}
\hline Province & $n$ & $\begin{array}{c}\text { Buys } \\
\text { lambs (\%) }\end{array}$ & $\begin{array}{l}\text { Average number } \\
\text { of batches per year }\end{array}$ & $\begin{array}{l}\text { Average number } \\
\text { of lambs per batch }\end{array}$ & $\begin{array}{l}\text { Preferred age at } \\
\text { buying (months) }\end{array}$ & $\begin{array}{c}\text { Preferred weight } \\
\text { at buying (kg) }\end{array}$ \\
\hline Aleppo & 43 & 77 & $2.8 \pm 0.1 \mathrm{a}, \mathrm{b}$ & $119 \pm 33 \mathrm{a}$ & $4.2 \pm 0.3 \mathrm{a}, \mathrm{b}$ & $30.4 \pm 0.8 \mathrm{~b}$ \\
Damascus & 27 & 93 & $2.8 \pm 0.2 \mathrm{a}, \mathrm{b}$ & $254 \pm 36 \mathrm{~b}, \mathrm{c}$ & $4.6 \pm 0.3 \mathrm{~b}, \mathrm{c}$ & $29.4 \pm 1.0 \mathrm{~b}$ \\
Dayr az-Zor & 37 & 100 & $3.0 \pm 0.1 \mathrm{a}$ & $306 \pm 30 \mathrm{~b}$ & $5.3 \pm 0.3 \mathrm{~b}$ & $32.8 \pm 0.8 \mathrm{a}$ \\
Hama & 29 & 62 & $2.5 \pm 0.2 \mathrm{~b}$ & $227 \pm 44 \mathrm{~b}, \mathrm{c}$ & $3.9 \pm 0.4 \mathrm{a}, \mathrm{b}$ & $31.5 \pm 0.9 \mathrm{a}, \mathrm{b}$ \\
Hasakah & 31 & 97 & $2.7 \pm 0.2 \mathrm{a}, \mathrm{b}$ & $236 \pm 33 \mathrm{~b}, \mathrm{c}$ & $4.6 \pm 0.4 \mathrm{~b}, \mathrm{c}$ & $30.5 \pm 0.9 \mathrm{a}, \mathrm{b}$ \\
Homs & 46 & 100 & $2.6 \pm 0.2 \mathrm{a}, \mathrm{b}$ & $291 \pm 34 \mathrm{~b}$ & $3.7 \pm 0.3 \mathrm{a}$ & $31.3 \pm 0.7 \mathrm{a}, \mathrm{b}$ \\
Raqqah & 26 & 96 & $2.7 \pm 0.2 \mathrm{a}, \mathrm{b}$ & $192 \pm 36 \mathrm{a}, \mathrm{c}$ & $4.1 \pm 0.4 \mathrm{a}, \mathrm{b}$ & $31.1 \pm 1.0 \mathrm{a}, \mathrm{b}$ \\
Total & 239 & 89 & 2.7 & 232 & $4.3 \pm 1.7$ & $31 \pm 4.9$
\end{tabular}

Note: Different letters in a column indicate statistically significant difference $(P<0.05)$. The calculated numbers per province are based on averages. The calculated figures per province are least squares means 


\section{Feeding management}

Two thirds $(66 \%)$ of farmers produced and used feeds for fattening from own crops, this occurring particularly in cropping areas, e.g., Aleppo $(56 \%, n=41)$, Hama (66\%, $n=29)$, and Raqqah $(94 \%, n=17)$. Barley was the crop most commonly produced $(56 \%, n=158)$, a finding that accords with Bahhady et al. (1997).

Barley and wheat are available at subsidized prices (Jaubert 2000), but other feedstuffs are usually bought at private markets at prices influenced by availability and season. Most feeds were bought from local markets (94\%) or government run feed stores (58\%). The most commonly used feeds are barley (97\%), wheat bran (75\%), and cotton seed cake (58\%). Feeds like crushed faba beans, dry bread, dates, sugar and sugar beets, vetch, green barley, chickpeas, radish, onions, and soybean meal are also used, though to a lesser extent. Minerals and vitamins were generally not used while these deficiencies are common in the region (Thomson et al. 2003).

Most farmers $(86 \%, n=237)$ buy feeds per batch of lambs fattened. This increases the flexibility of the system and reduces the risk due to feed price increase. High quality feed is important, as most producers $(98 \%, n=241)$ are convinced that poor quality lead to production and health problems. Feed quality was followed in importance by feed prices (65\% of respondents), though responses across provinces varied $(P<0.05)$.

In addition to feeding their animals by hand, $72 \%$ of producers take their animals out for grazing. Almost half of these producers $(46 \%)$ graze their sheep near to their house and village, and of those producers, $28 \%$ mainly grazed their animals on stubble. As a general practice, farmers walk their lambs for $2-3 \mathrm{~h}$ a day.

\section{Marketing}

In agreement with Vercueil and Cummins (2003), all farmers expressed that the intensity of fattening depends on the supply/demand for and prices of lambs for fattening, which is affected by seasonal fluctuation, market exports, and occurrence of annual festivities.

Farmers $(78 \%, n=206)$ preferred to buy animals at local bazaars and markets. Selling of finished lambs varied according to market demand, export possibilities, and annual festivities, though the selling threshold is when lambs reach $50-60 \mathrm{~kg}$ weight. Farmers prefer to sell in markets where lambs can be weighed as opposed to transactions made eye-weight estimates.

For most farmers $(91 \%)$, the middlemen help in buying lambs for fattening and selling finished lambs. By keeping the purchased lambs before handing them to farmers, the middlemen act as a mechanism that ensures that lambs are healthy and not stolen. Middlemen have a role in money handling for farmers either while buying or selling, expediting waiting times. Thus, the relationships between middlemen and farmers, the informal lending systems, and the peculiarities of the feed acquisition will be key factors to consider in technology implementation.

The lamb's health is a major concern from a marketing viewpoint, particularly in provinces having international boundaries where it is likely that illegal trade of animals takes place without proper health control.

Main constraints

\section{Structural constraints}

About $53 \%$ of farmers face problems in supplying water to their animals. Some overcome this constraint by purchasing water $(35 \%)$, since only $18 \%$ of producers have their own well or, in $22 \%$ of the cases, by obtaining water from a communal well.

Other constraints included inadequate ventilation in stables $(13 \%)$, and wet lambs and stables $(20 \%)$ due to lack of roof and inadequate flooring. Research is needed to assess local knowledge and identify best-bet options already developed by farmers, to then consider their improvement.

\section{Institutional constraints}

These encompass marketing and networking, the inadequate price, export, animal health, and credit access policies which have already been pointed out by Oram (1998) and Rahman (2008). No technical information is available for farmers initiating into or already in fattening work.

For half $(52 \%)$ of the farmers, fluctuation in the selling and buying prices of lambs and opening and closing of international borders were identified as serious problems. The next half divided equally when selling in considering international price (24\%) and cost-benefit margins (24\%), particularly for the more traditional fattening provinces. As long as credit is lacking and unfair practices prevail, i.e., intermediaries' high interest rates exceeding profit margins, farmers may fail to capture the market opportunity. While considering these constraints, consideration of lessons learned from associative production systems (Wilson 2004) and adequate policy development would be key.

\section{Production constraints}

For most farmers $(65 \%, n=241)$ the major constraint was feeding costs. This was due to the prices for feeds per se $(42 \%, n=241)$ and the fluctuation in price during the year (43\% of farmers). Feed availability was a constraint for 
$13 \%$ of the interviewed. Farmers feed their animals based on their own knowledge, mostly using unbalanced diets including expensive ingredients or concentrates. In 2007 and 2008, prices of barley grain and hay escalated disproportionally causing economic losses to farmers, some considering the halting of their operations.

For about a half of the farmers (51\%), lamb health was also a serious technical constraint. They reported seasonal disease fluxes, with implications on veterinary costs in controlling diseases and availability of drugs. The loss of a few lambs could constitute the loss of earnings, and the loss of the flock due to a disease outbreak, the loss of an important livelihood asset. Epidemiological research and adequate policies leading to simple but effective measures to avoid epidemiological episodes are needed.

In the spring and summer of 2007, all lamb shipments exported to Saudi Arabia were halted due to an outbreak of foot and mouth disease in Jordan. The outbreak forced middlemen to export lambs by sea, an added cost to be endured by the farmers as prices dropped. A follow-up interview at the Aleppo sheep market in 2007 and 2008, it was found that farmers began to support the idea of certified testing and prefer to sell through middlemen following this practice before export (Birgitte Hartwell, personal communication, 2009).

\section{Lamb fattening systems}

Three clusters of production systems with distinctive characteristics were found (Table 2). Two clusters ( $\mathrm{C} 1$ and $\mathrm{C} 2$ ) included systems located in the drier areas, and the third cluster (C3) systems located in higher rainfall and peri-urban areas. Principal components accounting for nearly half of the total variation included years in fattening and number of family members involved in fattening operations.
C1 was the cluster with the largest incidence of systems (48\%), particularly concentrated in Hasakah. Though farmers in these systems are relatively new (13 years in fattening), they fatten animals at an intensive rate with a high number of batches per year (2.6 batches) and lambs per batch (159 head). The use of family labor in these systems is low.

C2 included systems featuring highly intensive production, with the maximum average of batches per year (3.2 batches) and maximum number of lambs per batch (388 head). This cluster group, mainly located in Dayr az-Zor and Homs, has long experience in fattening and makes intensive use of family labor.

The systems in cluster $\mathrm{C} 3$ second those of $\mathrm{C} 2$ in intensiveness, on the basis of number of batches per year ( 2.7 batches) and lambs per batch (152 head). The cluster also involves the more traditional and experienced fattening operations, mainly located in Aleppo, Damascus, and Hama including many peri-urban areas. Apparently, many of these oldest systems, in particular, those of peri-urban areas, are shifting towards other drier areas, in view of high disease incidence.

The clusters show that large numbers of farmers from non-traditional lamb fattening areas, with less experience, are engaging in lamb fattening operations $(\mathrm{C} 1)$. There will be a crucial need to support these farmers for sustainable and viable production, ensuring best managerial, environmental, and ethical practices.

\section{Conclusions}

Due to market opportunities and favorable prices for lamb meat, intensive lamb fattening seems to be a profitable enterprise, income-generating option and a source of family. Middlemen are important players in buying and

Table 2 Fattening production systems in clusters and their characteristics

\begin{tabular}{llll}
\hline Main features and distribution & \multicolumn{1}{l}{ Clusters } & & \\
\cline { 2 - 4 } & $\mathrm{C} 1$ & $\mathrm{C} 2$ & $\mathrm{C} 3$ \\
\hline Years in fattening & $12.9 \pm 0.8$ & $21.7 \pm 1.9$ & $30.5 \pm 2.1$ \\
Family members & $10.0 \pm 0.4$ & $16.7 \pm 1.7$ & $16.2 \pm 1.2$ \\
Fatteners in the area & $17.1 \pm 2.6$ & $115.0 \pm 20.0$ & $16.6 \pm 3.4$ \\
Fattening batches per year & $2.6 \pm 0.1$ & $3.2 \pm 0.2$ & $2.7 \pm 0.1$ \\
Lambs fattened per batch & $159.0 \pm 9.2$ & $388.0 \pm 30.5$ & $151.6 \pm 13.9$ \\
Percent of interviewed systems & 48 & 27 & 25 \\
Main distribution area & Hasakah & Dayr az-Zor & Aleppo, Damascus and Hama (peri-urban) \\
Secondary distribution area & All other provinces except Hama & Homs & Hama, Dayr az-Zor and Hasakah \\
\hline
\end{tabular}

Note: Years in fattening, number of family member, number of fatteners in the area, batches per year, and number of lambs fattened per batch were main principal components accounting for $26 \%, 20 \%, 18 \%, 14 \%$, and $13 \%$ of the total data variability 
marketing lambs. Thus, their role should be taken into account in the improvement of these systems.

Feeding costs and animal health were identified as major constraints. Feeding costs could be reduced by using leastcost diets and strategic feeding during the fattening period, while health problems could be curbed through adequate flock management. However, while it would be relatively simple to reduce feeding costs, since a large variety of feed resources are available, research alone may not be able to minimize the health problem. Adequate policies are needed.

Further research is needed to identify "best-bet" practices already tested by farmers. A broader economic analysis of the production systems associated with fattening and an in-depth analysis of the export trade are also needed. This to identify policies that are conducive to creating locally and regionally enabling conditions for production and trade.

It is expected that due to existing commonalities, the information emerging from this study regarding major constraints to Awassi lamb fattening systems could be useful for an across-synthesis on Awassi fattening production in the region or other regions with similar fattening systems to those of developing Middle Eastern countries.

Acknowledgements Thanks are extended to the Ministry of Foreign Affairs in Denmark and Austria for providing the funds for this study and to all participating farmers, Safouh Rihawi, Monika Zaklouta, and Salwa Salam for their kind help.

\section{References}

Bahhady, F., Thomson, E.F. and Boulad, M., 1997. Red meat production, marketing and trade in Syria. In: T. Belhadj, J.P. Boutonnet and A. Di Giulio (eds), Filière des viandes rouges dans les pays méditerranéen. Red meat industry in the Mediterranean countries: CIHEAM-IAMZ, (Options Méditerranéennes : Série A. Séminaires Méditerranéens; n. 35). Séminaire International sur la Filière des Viandes Rouges dans les Pays Méditerranéens, Zaragoza, 1998, 89-100.

Baltenweck, I., Staal, S. and Ibrahim, M.N.M., 2004. Demand-driven crop-ruminant intensification: trans-regional analysis to understand patterns of change using village level data from three countries. In: E. Owen, T. Smith, M.A. Steele, S. Anderson, A.J. Duncan, M. Herrero, J.D. Lever, C.K. Reynolds, J.I. Richards and J.C. Ku-Vera (eds), Responding to the livestock revolution: the role of globalization and implications for poverty alleviation. British Society of Animal Science. Nottingham University Press, UK, 155-166.

Delgado, C., Rosengrant, M., Steinfeld, H., Ehui, S. and Courbois, C., 1999. Livestock to 2020: The Next Food Revolution. 2020 Vision Initiative, Food, Agriculture and the Environment. Discussion Paper 28. International Food Policy Research Institute (IFPRI), Washington, DC, USA.
Hartwell, B.W., Inigues, L., Knaus, W.F. and Madsen, J. 2010 (In press). Awassi lamb growth responses and carcass traits, and economic benefits associated with reduced-cost diets made from locally available feed resources. J. Small Ruminant Research.

Jaubert, F., 2000. Government Policy and Productive Systems in the Arid Regions of Syria since 1930s. In: M. Mundy and B. Musallam (eds), The transformation of Nomadic Society in the Arab East. Cambridge University Press, UK, 99-109.

Oram, P., 1998. The Influence of Government Policies on Livestock Production and the Environment in West Asia and North Africa (WANA). In: A.J. Nell (ed), Livestock and the Environment. International Conference. FAO, WB and IAC. Available at: http:// www.fao.org/WAIRDOCS/LEAD/X6144E/X6144E00.HTM. Last Accessed on February 5, 2010.

Parente, H.N., Machado, T.M.M., Carvalho, F.C., Garcia, R., Rogério, M.C.P.,Barros, N.N.N., Zanine, A.M. 2009. Desempenho produtivo de ovinos em confinamento alimentados com diferentes dietas [Performance of confined sheep fed different diets]. Arq. Bras. Med. Vet. Zootec., 61 (2): 460-466

Pinos-Rodríguez, J.M., Velásquez-Blanco, J.C., González-Muñoz, J. C., García-López, J.C., Aguirre-Rivera, J.R. and Bárcena, R. 2007. Evaluation of cactus pear (Opuntia ficus-indica) as forage in a high concentrate total mixed ration on finishing lambs. J. Appl. Anim. Res., 32: 161-164

Rahman, S.A. 2008. Middle East. In: Long distance transport and welfare of farm animals. Appleby, M.C., Cussen, V., Garcés, L., Lambert, L. and Turner, J. (eds). CAB International, Walling ford, Oxfordshire, UK.

SAS Institute Inc., 1992. SAS/STAT User's Guide. Volume $1+2$, Version 6, Fourth Edition, SAS Institute Inc., Cary, NC. USA.

Thomson, E.F., Martini, M.A. and Tutwiler, R.N., 2003. Sheep Management Practices in Iraq, Jordan and Syria: The Case of Reproduction and Fertility. Integrated Natural Resource Management. Technical Research Report Series, No. 2, ICARDA, Aleppo, Syria.

Upton, M. and Otte, J., 2004. The impact of trade agreements on livestock production. In: E. Owen, T. Smith, M.A. Steele, S. Anderson, A.J. Duncan, M. Herrero, J.D. Lever, C.K. Reynolds, J.I. Richards and J.C. Ku-Vera (eds), Responding to the livestock revolution: the role of globalization and implications for poverty alleviation. British Society of Animal Science. Nottingham University Press, UK, 67-84.

Vercueil, J. and Cummins, G., 2003. The livestock sector and policies in Syria. In: C. Fiorillo and J. Vercueil (eds.). Syrian agriculture at the crossroads. FAO Agricultural Policy and Economic Development Series 8, 219-246.

Wilson, R.T., 2004. Financing the livestock revolution in the developing world: givers and getters. In: E. Owen, T. Smith, M.A. Steele, S. Anderson, A.J. Duncan, M. Herrero, J.D. Lever, C.K. Reynolds, J.I. Richards and J.C. Ku-Vera (eds), Responding to the livestock revolution: the role of globalization and implications for poverty alleviation. British Society of Animal Science. Nottingham University Press, UK, 271286.

Zamudio, D.M., Pinos-Rodríguez, J.M., González, S.S., Robinson, P. H., García, J.C. and Montañez, O. 2009. Effects of Agave salmiana Otto Ex Salm-Dyck silage as forage on ruminal fermentation and growth in goats. Animal Feed Science and Technology, 148: 1-11. 